\title{
THE RENAL CLEARANCES OF IODIDE AND L-DIIODOTYROSINE MEASURED SIMULTANEOUSLY *
}

\author{
By WILLIAM E. LASSITER † AND JOHN B. STANBURY
}

\author{
(From the Department of Medicine, Harvard Medical School and the Medical Services of the \\ Massachusetts General Hospital, Boston, Mass.)
}

(Submitted for publication October 13, 1958; accepted January 5, 1959)

After the intravenous administration of $\mathrm{I}^{131}$ labeled L-diiodotyrosine (DIT), an increasing fraction of the labeled iodine of the serum becomes inorganic iodide as the DIT undergoes deiodination. Most of the labeled iodine which appears in the urine is inorganic iodide (1). If one makes an estimate of the renal clearance of inorganic iodide, based on the concentrations of labeled inorganic iodide in serum and urine after the administration of DIT, then values considerably in excess of those reported for iodide (2-5) are obtained. This could occur if DIT undergoes further deiodination after it enters the kidney.

The studies reported here are concerned with simultaneous measurements of the renal clearance of iodide and DIT, using a double-labeling technique with $\mathrm{I}^{133}$-labeled iodide and $\mathrm{I}^{131}$-labeled DIT. It is shown that the apparent renal clearance of $\mathrm{I}^{131}$-labeled DIT is considerably less than the true clearance and, thus, that intrarenal deiodination of DIT does indeed occur.

\section{MATERIALS AND METHODS}

DIT labeled with $\mathrm{I}^{131}$ was prepared by iodination of L-tyrosine by the method of Roche, Lissitzky, Michel and Michel (6). $I^{133}$ in the form of iodide was obtained from Brookhaven National Laboratories. The major component of the gamma radiation of $\mathrm{I}^{133}$ has an energy of 0.53 MEV. This is sufficiently different from the major $I^{131}$ gamma energy of $0.36 \mathrm{MEV}$ to permit differentiation of the two isotopes in a well-type scintillation counter with pulse-height analyzer.

Five subjects were selected for study. All were healthy males with no clinical evidence of renal disease or prostatism. The ages ranged from 29 to 63 years. In three of the subjects there was no thyroidal uptake of iodide because of previous thyroidectomy or medications, and in the other two (Subjects 2 and 5), uptake of iodine by the

* Supported in part by Grant No. A-1880 of the Division of Arthritis and Metabolic Diseases of the United States Public Health Service.

† Recipient of a Donner Fellowship for Medical Research. Present address: Department of Medicine, University of North Carolina, Chapel Hill, N. C. gland was blocked with a single $30 \mathrm{mg}$. dose of methimazole. All subjects were clinically euthyroid at the time of the study.

Priming doses of $50 \mu \mathrm{c}$. each of I ${ }^{131}$-labeled DIT and of $\mathrm{I}^{133}$ as iodide were given intravenously, and a maintenance solution containing $40 \mu \mathrm{c}$. of DIT and $20 \mu \mathrm{c}$. of iodide ${ }^{133}$ in $50 \mathrm{ml}$. saline was administered by continuous I.V. drip at the rate of $2 \mathrm{ml}$. per minute. After a 30 minute period for equilibration, urine collections were made for four consecutive 30 minute periods, with a blood sample at the midpoint of each period. The labeled iodine in aliquots of each urine and serum sample was determined in the well-type scintillation counter at discriminator settings for $I^{131}$ and $I^{133}$. Urine was then applied with carrier iodide and DIT directly to Whatman No. 3 filter paper for descending chromatography in butanol-20 per cent acetic acid. Because of the low concentration of labeled iodine in the serum samples, $2 \mathrm{ml}$. aliquots were first acidified to pH 2 with $\mathrm{H}_{2} \mathrm{SO}_{4}$ and thrice extracted with butanol saturated with 5 per cent $\mathrm{Na}_{2} \mathrm{~S}_{2} \mathrm{O}_{3}$. The butanol extracts were evaporated to dryness at $65^{\circ} \mathrm{C}$. and redissolved in ethanol $\mathrm{NH}_{3}$ prior to chromatography. After chromatography the strips were sprayed with palladium chloride and diazotized sulfanilic acid solutions to identify the iodide and DIT markers. Strips were then cut in segments and counted both for $\mathrm{I}^{181}$ and $\mathrm{I}^{133}$ in the well counter. Inulin clearances were simultaneously determined by the conventional method in three of the five patients.

In order to test the accuracy of the chromatographic method for measuring the relative quantities of DIT and iodide, normal serum was incubated with four different known ratios of DIT and iodide. Samples of each were extracted, chromatographed and measured as described. The results, shown in Table I, indicate that the method

TABLE I

Recovery of known amounts of $I^{131}$-labeled DIT and iodide after incubation with serum*

\begin{tabular}{cccc}
\hline Sample & $\begin{array}{c}\text { Labeled } \\
\text { iodine } \\
\text { added as } \\
\text { inorganic } \\
\text { iodide }\end{array}$ & $\begin{array}{c}\text { Labeled } \\
\text { iodine } \\
\text { recovered }\end{array}$ & $\begin{array}{c}\text { Labeled } \\
\text { iodine } \\
\text { recovered } \\
\text { as inorganic } \\
\text { iodide }\end{array}$ \\
\hline no. & $\%$ & $\%$ & $\%$ \\
1 & 24.1 & 73.5 & 22.6 \\
2 & 41.7 & 68.3 & 42.2 \\
3 & 61.0 & 66.0 & 60.2 \\
4 & 80.1 & 70.2 & 79.0
\end{tabular}

* Three successive $10 \mathrm{ml}$. butanol extractions of $2 \mathrm{ml}$. samples were chromatographed. 
provides a satisfactory indication of the ratio of concentration of the labeled substances in the serum samples. Losses in the processes of extraction, transfer and chromatography were random and did not affect the ratio after three extractions.

Computations. Because the $I^{123}$ available is contaminated with $\mathrm{I}^{131}$, it is necessary to apply a correction to the measured values of the labeled iodine in urine and serum at the two settings. This can be done by measuring known standards of $I^{131}$ and $I^{123}$ at the two settings on the pulse-height analyzer. Simultaneous equations can then be set up and solved as follows:

$$
\begin{aligned}
& A=x+a y \\
& B=b x+y
\end{aligned}
$$

where

$$
\begin{aligned}
& A=\text { observed counts of sample at } I^{131} \text { setting, } \\
& B=\text { observed counts of sample at } I^{133} \text { setting, } \\
& x=\text { true } I^{131} \text { counts, } \\
& y=\text { true } I^{133} \text { counts, } \\
& a=\text { counts of } I^{132} \text { standard at } I^{131} \text { setting } \\
& \text { counts of } I^{133} \text { standard at } I^{133} \text { setting } \\
& \text { b }=\frac{\text { counts of } I^{131} \text { standard at } I^{133} \text { setting }}{\text { counts of } I^{131} \text { standard at } I^{131} \text { setting }}
\end{aligned}
$$$$
\text { and }
$$

The values of $\mathrm{x}$ and $\mathrm{y}$ determined by the solution of these equations can then be applied directly to the computation of the renal clearances (C) of $\mathrm{I}^{131}$ and $\mathrm{I}^{133}$, viz.

$\mathrm{C}_{\mathrm{I}^{12}}=\frac{\text { corrected urine } \mathrm{I}^{123} \text { counts } X \text { volume of urine }}{\text { corrected serum } \mathrm{I}^{123} \text { counts } X \text { duration of collection }}$

provided equal volumes of urine and serum are counted. The $\mathrm{C}_{\mathrm{I}^{12}}$ was a true measure of the renal clearance of iodide, since it was shown by chromatography that all of the $I^{133}$ in both serum and urine was present solely as iodide. The overall clearance of $\mathrm{I}^{131}$, which can be computed in similar fashion, is a function of both the iodide and DIT clearances.

The fraction of the total $\mathrm{I}^{131}$ present as iodide and as DIT was determined by chromatography of urine and serum samples. From these data, an apparent renal clearance of DIT can be computed which is related to the overall clearance of $\mathrm{I}^{181}\left(\mathrm{C}_{\mathrm{I}^{121}}\right)$ as follows:

$$
\text { App. } C_{\text {DIT }}=\frac{f_{\text {DIT }} \text { urine }}{f_{\text {DIT }} \text { serum }} \times C_{I^{121}}
$$

where $f_{D I T}$ urine equals the fraction of total urinary $I^{131}$ present as DIT and $f_{\text {DIT }}$ serum equals the fraction of total serum I'181 present as DIT. $f_{\text {DIT }}$ urine is always small. Similarly, an apparent renal clearance of iodide can be computed.

The true clearance of DIT is the apparent clearance plus an amount of DIT equivalent to any iodide which may have been split from DIT during passage through the kidney. Thus, the last term of Equation 1 below is an expression to add to the clearance value that iodide in the urine which was derived by breakdown of DIT in the kidney. If there were no breakdown in the kidney, the numerator of this term would vanish.
1) $\quad$ True $C_{\text {DIT }}=\frac{U_{\text {DIT }}}{\mathrm{S}_{I^{121}} \cdot f_{\text {DIT }} \text { serum } \cdot T}$

$$
+\frac{U_{I^{121}}--S_{I^{121}}-\cdot C_{I^{12} \cdot T}}{S_{I^{121}} \cdot f_{D I T} \operatorname{serum} \cdot T}
$$

2) True $C_{D I T}=\frac{U_{D I T}+U_{I^{i 21}-}}{S_{I^{121} \cdot f_{D I T}} \text { serum } \cdot T}-\frac{S_{I^{181}}-\cdot C_{I^{122}} \cdot T}{S_{I^{121} \cdot f_{D I T}} \text { serum } \cdot T}$

$$
\text { 3) } \quad \mathrm{C}_{\mathrm{I}^{121}}=\frac{\mathrm{U}_{\mathrm{DIT}}+\mathrm{U}_{\mathrm{I}^{121}-}}{\mathrm{S}_{\mathrm{I}^{121} \cdot \mathrm{T}}}
$$

4) True $C_{D I T}=\frac{C_{I^{121}}-f_{I^{121}-\cdot} C_{I^{12}}}{f_{D I T} \text { serum }}$

where

$$
\begin{aligned}
\mathrm{U}_{\mathrm{DIT}}= & \text { total labeled DIT in urine during a collection } \\
& \text { period, } \\
\mathrm{U}_{\mathrm{I}^{121}}= & \text { urine labeled inorganic iodide, } \\
\mathrm{S}_{\mathrm{DIT}}= & \text { serum labeled DIT per unit volume, } \\
\mathrm{S}_{\mathrm{I}^{121}}= & \text { serum labeled inorganic iodide, } \\
\mathrm{S}_{\mathrm{I}^{121}}= & \text { total serum } \mathrm{I}^{131}, \\
\mathrm{C}_{\mathrm{I}^{12}}= & \text { total clearance of } \mathrm{I}^{128}, \text { or inorganic labeled } \\
& \text { iodide clearance, } \\
\mathrm{f}_{\mathrm{DIT}} \text { serum }= & \text { fraction of serum } \mathrm{I}^{131} \text { present as DIT, } \\
\mathrm{f}_{\mathrm{I}^{121}}= & \text { fraction of serum } \mathrm{I}^{181} \text { present as inorganic } \\
& \text { iodide, and by definition equal to } \mathrm{S}_{\mathrm{I}^{121}-/ \mathrm{S}_{\mathrm{I}^{121}},}
\end{aligned}
$$

and

$$
\mathrm{T}=\text { time. }
$$

\section{RESULTS AND DISCUSSION}

Values for $\mathrm{C}_{\mathrm{I}}{ }^{183}, \mathrm{C}_{\mathrm{I}}{ }^{131}$ and the apparent and true clearances of DIT for each of the five subjects are summarized in Table II. In Subject No. 5, the first collection period was discarded because an equilibrium state had not been reached, and $C_{D I T}$ could not be computed for the final period because of laboratory contamination of the chromatograms. Considerable individual variation in the renal clearance of iodide $\left(\mathrm{C}_{\mathrm{I}}{ }^{133}\right)$ was noted. The highest values were found in younger subjects. In the two youngest subjects, clearance values somewhat higher than those recorded in the literature (2-5) were found. There was also considerable variation in the apparent and true clearance of DIT, the ratios varying from 0.2 to 0.55 . This is presumably attributable to varying degrees of deiodination of DIT in the kidney.

In each case, the true clearance of DIT was found to be greater than the apparent clearance, as estimated from serum and urine DIT concentrations. Thus, postglomerular, presumably intrarenal, deiodination of DIT must have occurred. This could have taken place either by deiodination of filtered DIT, or by direct secretion of de- 
WILLIAM E. LASSITER AND JOHN B. STANBURY

TABLE II

Renal clearance of diiodotyrosine (DIT) and of iodide in five male subjects*

\begin{tabular}{|c|c|c|c|c|c|c|c|c|c|c|}
\hline Period & & $\mathrm{C}_{\mathbf{I}^{181}}$ & Errort & $\begin{array}{c}\mathrm{C}_{\text {I123 }^{123}} \\
\text { (iodide) }\end{array}$ & Errort & $\begin{array}{l}\text { Apparent } \\
\text { CDIT }\end{array}$ & Errort & $\begin{array}{l}\text { True } \\
\text { CDIT }\end{array}$ & Error‡ & $\begin{array}{c}\text { Inulin } \\
\text { clearance }\end{array}$ \\
\hline \multirow{2}{*}{$\begin{array}{l}\text { Pt. No. } 140 \\
1 \\
2 \text { (60 min.) } \\
3\end{array}$} & \multirow{2}{*}{$\mathbf{M}$} & \multicolumn{2}{|c|}{ ml. $/ \min$} & \multicolumn{2}{|c|}{ ml. $/$ min. } & \multicolumn{2}{|c|}{ ml./min. } & \multicolumn{2}{|c|}{ ml./min. } & ml. $/ \min$. \\
\hline & & $\begin{array}{l}23.2 \\
20.4 \\
21.5\end{array}$ & $\begin{array}{l} \pm 0.6 \\
\pm 0.5 \\
\pm 0.6\end{array}$ & $\begin{array}{l}38.2 \\
28.5 \\
27.8\end{array}$ & $\begin{array}{l} \pm 2.2 \\
\pm 1.6 \\
\pm 1.8\end{array}$ & $\begin{array}{l}3.2 \\
3.3 \\
3.6\end{array}$ & $\begin{array}{l} \pm 0.4 \\
\pm 0.4 \\
\pm 0.5\end{array}$ & $\begin{array}{l}20.2 \\
15.3 \\
16.9\end{array}$ & $\begin{array}{l} \pm 2.3 \\
\pm 1.7 \\
\pm 1.9\end{array}$ & \\
\hline Average & & 21.4 & & 30.8 & & 3.4 & & 16.9 & & \\
\hline $\begin{array}{cl}\text { Pt. No. } 2 & 36 \\
1 & \\
2 & \\
3 & \\
4 & \end{array}$ & $\mathbf{M}$ & $\begin{array}{l}28.8 \\
38.6 \\
38.2 \\
27.3\end{array}$ & $\begin{array}{l} \pm 0.9 \\
\pm 1.2 \\
\pm 1.0 \\
\pm 0.7\end{array}$ & $\begin{array}{l}51.0 \\
65.9 \\
56.7 \\
40.4\end{array}$ & $\begin{array}{l} \pm 2.7 \\
\pm 3.3 \\
\pm 2.6 \\
\pm 1.8\end{array}$ & $\begin{array}{l}4.2 \\
9.5 \\
6.6 \\
5.0\end{array}$ & $\begin{array}{l} \pm 0.6 \\
\pm 1.8 \\
\pm 1.2 \\
\pm 0.9\end{array}$ & $\begin{array}{l}17.7 \\
22.4 \\
25.7 \\
13.5\end{array}$ & $\begin{array}{l} \pm 2.9 \\
\pm 3.5 \\
\pm 2.8 \\
\pm 1.9\end{array}$ & . \\
\hline Average & & 33.2 & & 53.5 & & 6.3 & & 19.8 & & \\
\hline $\begin{array}{cl}\text { Pt. No. } 3 & 63 \\
1 & \\
2 & \\
3 & \\
4 & \end{array}$ & $\mathbf{M}$ & $\begin{array}{l}17.5 \\
17.6 \\
15.1 \\
17.2\end{array}$ & $\begin{array}{l} \pm 0.4 \\
\pm 0.4 \\
\pm 0.4 \\
\pm 0.4\end{array}$ & $\begin{array}{l}29.8 \\
29.0 \\
23.1 \\
24.4\end{array}$ & $\begin{array}{l} \pm 1.5 \\
\pm 1.7 \\
\pm 1.5 \\
\pm 1.6\end{array}$ & $\begin{array}{l}5.0 \\
4.1 \\
2.9 \\
3.7\end{array}$ & $\begin{array}{l} \pm 0.6 \\
\pm 0.8 \\
\pm 0.6 \\
\pm 0.8\end{array}$ & $\begin{array}{l}11.8 \\
11.1 \\
10.0 \\
11.1\end{array}$ & $\begin{array}{l} \pm 1.6 \\
\pm 1.8 \\
\pm 1.6 \\
\pm 1.7\end{array}$ & $\begin{array}{l}77.0 \\
83.8 \\
68.8 \\
84.0\end{array}$ \\
\hline Average & & 16.8 & & 26.6 & & 3.9 & & 11.0 & & 78.1 \\
\hline $\begin{array}{cl}\text { Pt. No. } 4 \quad 29 \\
1 \\
2 \\
3 \\
4\end{array}$ & $\mathbf{M}$ & $\begin{array}{l}40.5 \\
42.8 \\
46.4 \\
50.3\end{array}$ & $\begin{array}{l} \pm 0.8 \\
\pm 0.9 \\
\pm 1.1 \\
\pm 1.4\end{array}$ & $\begin{array}{l}65.5 \\
69.6 \\
68.0 \\
71.1\end{array}$ & $\begin{array}{l} \pm 3.1 \\
\pm 3.6 \\
\pm 3.6 \\
\pm 4.6\end{array}$ & $\begin{array}{l}8.8 \\
7.2 \\
6.1 \\
9.4\end{array}$ & $\begin{array}{l} \pm 0.9 \\
\pm 0.9 \\
\pm 0.9 \\
\pm 2.4\end{array}$ & $\begin{array}{l}28.8 \\
23.2 \\
30.2 \\
31.3\end{array}$ & $\begin{array}{l} \pm 3.2 \\
\pm 3.7 \\
\pm 3.8 \\
\pm 4.8\end{array}$ & $\begin{array}{r}103.4 \\
90.7 \\
84.9 \\
77.5\end{array}$ \\
\hline Average & & 45.0 & & 68.5 & & 7.8 & & 28.4 & & 89.1 \\
\hline $\begin{array}{cl}\text { Pt. No. } 5 \quad 60 \\
1 \\
2 \\
3\end{array}$ & $\mathbf{M}$ & $\begin{array}{l}19.9 \\
21.0 \\
17.6\end{array}$ & $\begin{array}{l} \pm 0.7 \\
\pm 0.7 \\
\pm 0.7\end{array}$ & $\begin{array}{l}30.1 \\
29.0 \\
25.9\end{array}$ & $\begin{array}{l} \pm 1.7 \\
\pm 1.6 \\
\pm 1.4\end{array}$ & $\begin{array}{l}5.2 \\
4.8\end{array}$ & $\begin{array}{l} \pm 1.4 \\
\pm 1.4\end{array}$ & $\begin{array}{r}7.4 \\
10.8\end{array}$ & $\begin{array}{l} \pm 1.8 \\
\pm 1.7\end{array}$ & $\begin{array}{l}69.6 \\
59.2 \\
53.2\end{array}$ \\
\hline $\begin{array}{c}\text { Average } \\
\text { periods } \\
2-3\end{array}$ & & 20.4 & & 29.5 & & 5.0 & & 9.1 & & 64.4 \\
\hline
\end{tabular}

* $\mathrm{C}_{\mathrm{I}^{121}}$ is the observed overall clearance of $\mathrm{I}^{131}$ after administration of $\mathrm{I}^{131}$-labeled DIT. $\mathrm{C}_{\mathrm{I}^{132}}$ is the clearance of $\mathrm{I}^{188}$ administered simultaneously as inorganic iodide. C $C_{\text {DIT }}$ is the clearance of DIT.

$\dagger$ Errors of counting only expressed as standard deviation.

$\ddagger$ Square root of sum of square of $I^{131}$ and $I^{133}$ counting errors.

rived iodide by the cells of the kidney tubules. Deiodination in the ureters or bladder could conceivably occur but seems less likely. Deiodination did not occur in urine samples which were allowed to stand overnight at room temperature.

For any clearance studies to be valid, it is necessary that the substance being studied remain intact. DIT undergoes deiodination in the process of excretion; hence, it is not possible to estimate its true clearance by a single tracer technique. The true clearance can be calculated only if an independent measurement of the iodide clearance is obtained simultaneously, as by the double tracer technique described here.

\section{SUMMARY AND CONCLUSIONS}

1. Simultaneous determinations of the renal clearance of $\mathrm{I}^{131}$-labeled diiodotyrosine and $\mathrm{I}^{133}$ labeled iodide have been performed. Differential measurement of the two isotopes was found to be technically feasible.

2. The apparent renal clearance of diiodotyrosine is lower than the true clearance because of intrarenal deiodination of diiodotyrosine.

\section{ACKNOWLEDGMENTS}

The authors wish to acknowledge their indebtedness to Dr. Gordon Brownell and Dr. Alexander Leaf for help and advice, and for the inulin determinations. Dr. 
Pablo Fletcher assisted in the observations on the first two patients.

\section{REFERENCES}

1. Stanbury, J. B., and Litvak, J. The metabolism of iodotyrosines. IV. Metabolism of diiodotyrosine in patients with hypothyroidism. J. clin. Endocr. 1957, 17, 654.

2. Myant, N. B., Pochin, E. E., and Goldie, E. A. G. The plasma iodide clearance rate of the human thyroid. Clin. Sci. 1949, 8, 109.

3. McConahey, W. M., Keating, F. R., Jr., and Power, M. H. An estimation of the renal and extrarenal clearance of radioiodide in man. J. clin. Invest. 1951, 30, 778.

4. Perry, W. F., and Hughes, J. F. S. The urinary excretion and thyroid uptake of iodine in renal disease. J. clin. Invest. 1952, 31, 457.

5. Becker, D. V., and Danzig, L. E. Kinetics of radioiodine distribution in chronic renal disease studied by means of the artificial kidney. Trans. Amer. Goiter Ass. 1954, 301.

6. Roche, J., Lissitzky, S., Michel, O., and Michel, R. Etude radiochromatographique des étapes de ioduration de la tyrosine et de l'histidine. Biochim. biophys. Acta 1951, 7, 439. 